\title{
Teacher's Identity, Marketization of Higher Education, and Curriculum
}

\author{
Yaghoob Javadi \\ Department of Language Teaching and Translation, Varamin-Pishva Branch, Islamic Azad University, Varamin, Iran \\ Solmaz Azizzadeh Asl \\ Department of Language Teaching and Translation, Varamin-Pishva Branch, Islamic Azad University, Varamin, Iran
}

\begin{abstract}
For a long time, education has been praised as a morality in itself. Great philosophers have proudly called themselves "teachers", and education was considered a special gift given to young gifted people. But in today's world, in which everything, including even human feelings, have changed and become commodified, education has not been an exception. There have been many changes in education such as internationalization, increased competition and cooperation, neoliberalism, marketization, privatization, and new teaching methods. The idea that education is simply another market commodity has become pervasive in different discourses. Marketization which is one of the consequences of neoliberalism policies is an attempt that appraises everything related to higher education based on a market, where demand and supply and all the educational activities are determined and evaluated based on the price mechanism (Brown, 2014). This trend has fundamental effects on different aspects of the higher education including teacher's identity and curriculum design. In this article, the researcher defines the concept of identity and then describes the type of teacher's identity that is promoted by the marketization of higher education. Also, characteristics and some of the consequences of marketization of higher education and the effects of such trend on curriculum design are discussed.
\end{abstract}

Index Terms - teacher's identity, marketization, higher education, curriculum

\section{INTRODUCTION}

In today's world, we live in societies and work for economies which are technology driven and knowledge-based and knowledge itself is considered as an industry (Calzolari, 2010; Günder, 2009; Peters, 2002; Gibbons, et. al., 1994). Revolutions in the world of technology and telecommunication make the knowledge the main source for production and productivity (Kurtoglu, 2008), increasing the need for qualified workforce. In such a world, the role of higher education institutions in society and economy increases (YÖK, 2007). The world of higher education has evolved considerably, and important changes such as higher registration of students in nonnative countries' educational institutions, the increasing numbers of international students, and neoliberalism policies like marketization, privatization, and higher market-oriented competitions have emerged. One of the main revolutions which has become pervasive around the world is marketization of higher education. As Brown (2014) suggests one of the main consequences of neoliberalism policies is corporatization and marketization of the higher education which is based on the premise that the market can be the primary source of cultural logic and value, and it can substitute the democratic state. Neoliberalism promotes marketization policies and assigning services to the private sector instead of government, and it is one of the most important terms that should be well-understood in humanities and social studies. The neoliberal reforms emphasize the central role of markets in the governance of society, and advocate for minimal state involvement and intervention. In practice, this means enforcing actions, including: marketization and privatization. Marketization is an attempt that appraises everything related to higher education based on market, where demand and supply and all the educational activities are determined and evaluated based on the price mechanism (Brown, 2014).

One of the most important influences of marketization is related to teacher's identity. As McKoen and Harrison (2010) suggest, identity is a socially and culturally "self" that is shaped through the communication with the experiences that are gained in one's life. Identity is not fixed; it is ever-changing and continually under construction. It is a lifelong continuum which is created through social interactions and processes (Berger \& Luckmann, 1991). Teacher's identity is also the product of interaction between personal beliefs of teaching, understanding of the self, and social and occupational situations (Kreber, 2010). Scholars increasingly emphasize that teacher's identity is an integral part of the teaching profession (Rodgers \& Scott, 2008). Changes on a global scale require teachers to adapt to new roles in order to keep up with continuous diversifications in society (Thomas \& Beauchamp, 2010). This adaptation on the part of teachers requires them not only new knowledge acquisition but also learning in broader social context. As teachers' learning can be characterized as professional identity building (Timoštšuk, 2011), the experiences of the teachers that are gained through changes in the society are very important for forming and transforming teachers' 
identity. In the present article, some of the required adaptations and modifications of the teacher's identity in the light of marketization are discussed.

The other important element which is under the influence of marketization is curriculum. As Richards (2001) declares, curriculum design is a term that encompasses the purposeful and systematic organization of the course, and it is one of the important elements of the education that support it to be a good system and result a good output. But curriculum design, just like teacher's identity, is a field that is strongly influenced by marketization trend and requires some adaptations that may not be acceptable and satisfactory for many working in the field. In this article the trend of marketization of higher education and its relationship with teacher's identity and curriculum is discussed.

\section{TEACHER'S IDENTITY}

Identity has always been an important issue in the social and cultural studies. Poets, playwrights, and novelists are also interested in creating artworks in which identity changes in different conditions. As an example, in The Late Mattia Pascal (1964) which is Piranddello's novella, there is a man who fakes his death to start living with different identity only because his previous 'self' prevents routs to the new 'self' that he desires. We all have read and seen similar events in different stories, movies and so on. According to Danielewicz (2001), identity is our understanding of who we are and of who we think other people are. Reciprocally, it also encompasses other people's understanding of themselves and others (including us). Identity is not fixed; it is ever-changing and continually under construction. Danielewicz (2001) asserts that "Every person is composed of multiple, often conflicting, identities, which exist in volatile states of construction or reconstruction, reformation or erosion, addition or expansion" (p. 10).

Teacher's identity in the educational context is the matter of current article. Scholars believe that teacher's identity is central to the teaching profession (Rodgers \& Scott, 2008). The teacher's identity formation is an ongoing process which includes interpretation and reinterpretation of who one perceives oneself to be and who one would like to become (Beijaard et al., 2004). Teachers who identify with their teaching roles get an emotional attachment to their roles, and it reflects their worldview (Holland \& Lachicotte, 2007). Scholars also claim that this kind of attachment makes the role as a part of teacher's personality (Akkerman \& Meijer, 2011; Beauchamp \& Thomas, 2009).

Clarke (2008) frames identity as individual' knowledge and naming of themselves and also others' recognition of them as a particular sort of person. Danielewicz (2001) writes, 'I regard 'becoming a teacher' as an identity forming process whereby individuals define themselves and are viewed by others as teachers" (p. 4). Specifically in the context of language teaching, Varghese et al. (2005) argue that "In order to understand language teaching and learning we need to understand teachers: the professional, cultural, political and individual identities which they claim or which are assigned to them" (p. 22). Actually, processes of identity formation are related to the discourses and the communities that we live and work within.

There are a variety of theoretical approaches to teacher's identity; some put emphasis on the social and cultural essence of this phenomenon, while others believe that its discursive and narrative nature is of great importance. Most today's approaches, however, believe that identity is socially embedded, and it is not fixed but dynamic and changing (Rodgers \& Scott, 2008). Teacher's identity is not made in a vacuum, but its development is dependent upon social and cultural contexts (Holland \& Lachicotte, 2007; Penuel\&Wertsch, 1995).

Lankveld and his colleagues (2016) conducted a study on teacher's identity and discussed identity formation from different perspectives. Firstly, they worked on the teachers who entered higher education institutions from a professional background (like music or primary education) and concluded that these teachers strongly identified with their former professions, especially at the first years of teaching profession, and they primarily consider themselves as professionals rather than teachers. During early years of the profession, teachers feel stressful and insecure, and they believe that they are not good enough for their new role. This phase has a life of 1.5 to 3 years and even more. After almost three years being a teacher becomes a part of their identity. Lankveld, et al. (2016) also pointed to psychological and contextual factors that have different effects on teacher's identity formation. Regarding psychological factors they have pointed to: a sense of appreciation, connectedness, competence, commitment, and imaging a future career trajectory which are all psychological factors that have facilitating or constraining effect on teacher's identity development. They also believe that there are four contextual factors that facilitate or inhibit the formation of teacher's identity: first, the direct work environment, second, the wider context of higher education, third, interaction with students, and fourth staff development activities. They conclude that two last factors are facilitating the process of identity development, whereas the second factor has a constraining effect, and the first one can either be facilitator or inhibitor.

As a matter of fact, when the working environment is supportive and collegial teachers get a better feeling and become a member of the team. Instead, when the environment is competitive, and the research is overvalued to teaching, teachers feel isolated and the ideal identity development doesn't take place. Regarding the second factor which is the context of higher education, there are two levels: national and international. At both level, the effect of neoliberal management culture and the challenge in teaching-research relationship is debated and studies reflect the criticisms regarding the lack of creativity, autonomy, and trust which leads to tensions in teacher identities. As it was mentioned, Lankveld, et al. (2016) consider the teacher-student interaction a positive influencing factor for teacher's identity. Most of the time, when teachers have interaction with their students, they feel that their efforts are mattered and appreciated 
which in turn strengthen their identity. The last contextual factor which is related to staff development programs is considered positive as these activities increase the confidence of the teachers, they also create a sense of connectedness to peers with whom they interact and exchange their ideas and get an educational language which provides them with the sense of being valued and credible in the institution.

\section{TEACHER's IDENTITY IN MARKETIZED EDUCATION}

The other issue is related to teacher's identity and its changes in response to educational reforms. Globalization, neoliberalism, and its trends have changed education dramatically, consequently teachers have faced great changes (Lai \& Lo, 2007). Globalization, neoliberalism, marketization and economic developments affect education constantly forcing teachers to change, and these changes occur at different levels. The marketization of education which considers education as a commodity and evaluates educational attempts based on a market view has become a common trend around the world and penetrated many educational aspects where teacher's identity is not an exception. Teachers are expected to be effective instructors but commercialized view of teaching impairs educational ideas and democratic values, which is in line with economic competition at individual, institutional and national levels.

As Lankved, et al. (2017) claim different studies which are conducted mostly in UK or Australia discuss the effect of neoliberalism and marketization on teacher's identity and conclude that this trend has a negative effect on it. He adds that teachers participated in these researches criticize neoliberal developments. As they perceive it as preventing creativity, creating complexities in teaching, and loosing freedom. They also believe that this trend creates tensions that lead to the sense of uncertainty and lack of stability.

Dugas et al. (2018) put the issue in another way. They believe that neoliberalism and marketization lead to institutional striving, which encourage allocating more time and resource on writing and researching rather than teaching alone. They claim that many American regional public universities have changed their perspectives in a way that most of them do not consider teaching effectiveness as a main criterion for promotion. Professors should be more identified as practitioners of their disciplines rather than members of their institutions (e.g., Finnegan \& Gamson, 1996; Morphew \& Huisman, 2002). These days research productivity is more important than old criteria like being accepted by students, which is one of the consequences of neoliberal point of view (Youn \& Price, 2009). Acording to Youn and Price (2009) the view that teaching effectiveness is the main criteria for promotion declined from 86 percent in 1969 to 59 percent in 1997, and the percentage of journal publication doubled in these years. As a result, teachers should make the required adaptations to keep up with the diversifications and expectations.

What is clear is that the marketization of higher education has significant implications for academic identity. Defining academic identity is not simple (Archer, 2008b; Feather, 2016; Henkel, 2000) because identity is defined in different ways (Beijaard, Meijer, \& Verloop, 2004; Fitzmaurice, 2013) and also because neoliberalism and marketization of education have had significant impacts on the institutional contexts in which these identities are shaped and reshaped (Bennett et al., 2016; Elkington \& Lawrence, 2012; Winter, 2009). The principle of agency is a common framework for identity which considers this concept as an ongoing individual project (Fitzmaurice, 2013). Wenger (1998) calls it 'learning trajectory' which aims to integrate last experiences and future expectations with the present situation. MacLure (1993) defines identity as a "network of personal concerns, values and aspirations against which events are judged and decisions are made" (p. 314). But Jenkins (1996) define it as a synthesis of self-definitions and definitions of 'self' which is offered by others. As a result, we can assume that identity is subject to continuous formation and reformation and also continuous negotiation with the social context (Fitzmaurice, 2013; Whitchurch, 2013).

Academic identities are shaped in negotiation with institutions and the relationships within them (Henkel, 2005; Winter, 2009). As it was mentioned research productivity and assessable outputs are two determinant factors of teacher's progress but they can also have some destructive outcomes. As an example, teachers are obliged to prove that they have the requirements of being a member of the educational system (Ruth, 2008).Teachers who are in the beginning years of their teaching profession feel this pressure more than others (Archer, 2008a, 2008b) and claim that this trend shifts the focus to the needs of the institution rather than individual identity concern. Another contradiction is related to the ones who reflect on "the new managerialism" as a means to improve the academic identity and others who consider it a factor which is in conflict with their desired identity (Tran, Burns, \& Ollerhead, 2017; Winter, 2009; Ylijoki, 2014).

As Fredriksson (2009) asserts the market demands affect the teacher's positions, and change the identities from autonomous professionals to service-oriented workers in a quasi-business environment. In such situation, teachers let the principal manage everything and they lose their freedom and authority. Teachers have to remain competitive and their employment is dependent on the marketing success. Teachers should show off their work to the outside world, so they must allocate extra time, money, and effort at the expense of teaching main activities, and at the expense of suffering higher workloads. Devaluation of teacher's professional values is another consequence of marketization that has a negative effect on their identities.

Job satisfaction is another issue that should be considered in this regard. Many researchers have studied the relationship between marketization of the profession and neoliberal emphasis on productivity and concluded that this trend has a negative effect on teachers' job satisfaction (Fredman \& Doughney, 2012; Lester, 2013; Vardi, 2009). Shin 
and Jung (2014) have done numerous researches in this field and the results of their studies which is related to 19 different countries show that such perspectives make the situation stressful and unsatisfactory. When they compared some academics of different countries in terms of job satisfaction, they realized that those with higher job satisfaction had higher intrinsic motivation in comparison with those who had extrinsic motivation focusing on productivity.

Another consequence of marketization is reflected in higher workload and more expectations for time usage which leads to higher administrative accountabilities and higher dissatisfactions (Kuntz, 2012). Fredman and Doughney (2012) had a similar research and concluded that marketization, and more focus on money treats the educational institution as "shop assistants in a retail environment" (p. 54). These statements reflect more tensions and more job dissatisfaction of the teachers and administrators. Copur (1990) also studied the issue of job dissatisfaction and concluded that one of the reasons for this feeling is the decreased level of autonomy on the part of the teachers. Administrators try to have more control on their teachers and other staffs which leads to the sense of losing autonomy and freedom. Some teachers don't have problem with productivity needs, their main problem with such view is the lack of control over their own work (Fredman \& Doughney, 2012). Although these statements regarding job satisfaction are important and different studies have conducted on them (for example, Bozeman \& Gaughan, 2011; Copur, 1990; Ryan et al., 2012), they are just one part of the identity negotiation and we don't concentrate on them more.

\section{MARKETIZATION OF HighER EdUCATION}

During the two last decades and in many parts of the world, we confronted a new trend trying to argue that the government is not the best system that can provide all people with instructional services (Heyneman, 2001). The subsequent reforms with the name of marketization, privatization, and so on have become widespread in many educational systems of the countries around the world. What we face in the developed and developing countries is a movement on a continuum which starts from decreasing the role of government and continues towards marketization and finally complete privatization (Whitty \& Power, 2000). Rapid changes and developments in the world of higher education including globalization, neoliberalism trends, higher registration in nonnative educational institutions, increased rate of international students, and higher competitions among different educational institutions have occurred. A prevalent trend in higher education today in many countries around the world is the focus on marketization practices in higher education (Hemsley-Brown \& Lowrie, 2010; Taylor \& Judson, 2011). The corporatization and marketization of education have roots in neoliberal policies which offer a market view to education and consider it as a market commodity. As Brown (2014) suggests, marketization is an attempt that appraises everything related to higher education based on a market, where demand and supply and all the educational activities are determined and evaluated based on the price mechanism.

Nowadays universities are in the front line of marketization, and this changes the nature of the universities, their social functions, their educational goals, and the process of production and legitimating the knowledge and consequently the power relations (Giroux, 1999). As stated by Güla, Gülb, Kayab, and Alicanb (2010), information triangle consists of education and research, innovation, and creativity. In today's world, university is considered at the center of the information triangle and is capable of influencing $21^{\text {st }}$ century. Kafatos (2008), the President of European Research Council, asserts that university has a special importance in the areas of creativity and innovation along with the other vertex of the information triangle which is research and education.

Marketization of education leads to a point of view in which students are considered as consumers and universities act like corporations. Therefore, universities should be customer-oriented and do the best to attract customers. They should try for the best services and provide required information about their services, so that the ideal condition for free choice of the customers is created. But the fact is that when universities act like corporates, teachers lose their usual social position as a symbol of wisdom; they view education as a commodity, and they should focus on absorbing wealthy customers (Giroux, 2006). First of all, let's consider the theoretical model of Klein (1984) which encompasses the fourfold phases of the educational and financial resource allocation of the private and governmental sectors.

\section{KLEIN MODEL}

$\underline{\text { Financial Resources }}$

\begin{tabular}{|l|l|ll|}
\multicolumn{2}{l}{ Private } & Public & $\begin{array}{l}\text { Public } \\
\text { Educational } \\
\text { Provision }\end{array}$ \\
\hline 4 & 1 & 3 & Private
\end{tabular}

Figure 1: Allocation Model of Educational and Financial Resources (Klein, 1984)

Klein (1984) considers four states for the participation of government or private sector in education. In the first stage, the state is responsible for allocating both financial resources and educational services (teacher, curriculum, and others). 
In this stage, there is no intervention or support on the part of private sector. Politicians' justification for this stage is that education is fundamental in the destiny of the society so it shouldn't be influenced by the markets' trends. In the second stage, the state still is the decision-maker but providing financial resources is the responsibility of the private sector. So the private sector, mainly parents, is accountable for financial resources, and the state is responsible for educational policies. In this stage, people are considered as 'Customers'. This state is called Marketization of education. In the next stage, which is the third one, the state provides the private sector with facilities like loans. Decisions and policies regarding education, for example employing teachers, enrolling students, fund allocation and alike are undertaken by the private sector and are determined based on mechanisms and conditions of the market. In a country like Iran, 'Ministrant State' is the position of the government in this stage. In the last stage of Klein, the phrase 'Education without the State' can be used as the state doesn't have above mentioned responsibilities (Whitty \& Power, 2000). In this stage, government doesn't provide any subside and the process of education liberalization or complete privatization begins.

If we consider Iran as an example based on Klein Model, it has a contradictory condition. As stated by Modandar Arani, Kakia, and Moazeni (2010), Iran is using the second state in which private sector provides the financial resources, at the same time government is responsible for educational policies and all decisions are made by the state, and the private sector can't intervene and is considered as a customer. On the other hand, the government of Iran, India, and some other countries shares some facilities like loans to the private sector which reminds us the third stage of the Klein model. At the same time, some parts of Iran are interested in the fourth stage in theory but they in the first stage in practice. Some educational authorities claim that education is not exclusively private goods and it should be under supervision of the government. However, others believe that as education is not exclusively public goods, it cannot be governed exclusively by government (Alavitabar, 1990). Modandar, et al. (2010) claim that this kind or privatization which is observed in Iran is a semi-marketization of the governmental services.

\section{Vi. Challenges of Marketization of EduCATiON}

There are many studies that work on the effects of marketization on higher educational institutions especially universities and the findings show that higher education face different challenges through the way and marketization is a challenging trend for education. Judson and Taylor (2014) refer to the marketization of higher education as the increasing influence of market competition on academic life which leads to undesirable outcomes like creating an educational environment full of tension. Brown (2014) discusses marketization of higher education in terms of system effectiveness, information and consumer choice, quality, value for money, and the role of the state as different ironies of marketization. Regarding value for money, he claims that greater competition through decreasing costs and increasing quality is exactly what is needed. But obviously, too much competition is not desirable and damages the higher educational institution. As an example, Brown points to US "not for profit" colleges and English private schools in which providers over charge to have a better education. Allocating more financial resources to marketing and branding sector is considered as another undesirable consequence that should be considered. So the greater competition doesn't have favorable outcomes. Regarding system effectiveness, Brown (2014) concludes that systems with high degree of marketization are less effective than the others. He also claims that turning higher education to an economic good, which is the character of marketization, is unlike the broader liberal nature of education and damages the quality.

As Güla, Gülb, Kayab, and Alicanb (2010) state, one of the challenges of the present day is equal access to education which can be improved by distant education, e-learning, and other web-based information sharing methods. However, there is a need for more proofs to ensure the access of groups that are socioeconomically disadvantaged. Lower state participation and higher use of market strategies may have a negative effect on government funds available to universities and socioeconomically disadvantaged students, which in turn leads to marketization of higher education. In this environment, students and their families are treated like paying customers and this perspective which views students as consumers- 'consumerism'- leads to higher commercialization of education (Sperlich \& Spraul, 2007).

In western world, marketization of higher education is referred to both as "epidemic" (Natale \& Doran, 2012) and as "paradigm shift" (Newman \& Jahdi, 2009). Whitty and Power (2000) study the historical trends across the United States, England, Australia, and New Zealand and conclude that educational outcomes are not improving and the benefits of marketization of education have yet to be realized. Moelsworth, Nixon, and Scullion (2009) believe that marketization of higher education impedes the transformation of students to critical thinkers in the light of assuming students as consumers.

Decline of higher education as a public good is considered as another consequence of marketization of education which is conveyed by Judson and Taylor (2014). What is happening in the universities is that they are being asked to produce commercially oriented professionals rather than public-interest professionals (Hanlon, 2000). Lynch (2006) also blames marketization of education for different reasons. Changing culture and identity to adopt to the new role in the marketized environment are some of lamentable consequences of this trend as he suggested. Higher concentration on customer service is another feature that is also asserted by Cucchiara, Gold, and Simon (2011) who have studied this trend qualitatively.

Judson and Taylor (2014) also blame marketization of education and assert that many of students have no significant improvement in skills like critical thinking, complex reasoning, and writing which is not ignorable. Lundahl, et al. 
(2013) study the Swedish way of educational marketization and conclude that the resulting competitive environment has a negative effect on the performance of the schools and only a small group (less than 25 percent) of the respondents asserted a better performance. Most of the teachers and principals together with students are actively participating in marketing programs, and the time spent on these activities is the major cost. They use different ways to absorb potential students, such as advertisements in television and radio, internet, sending emails or text messages and have different attractive offerings like tickets or laptops. This competitive environment needs considerable time, energy, and effort and threatens the traditional fundamental professional values.

Giroux considers marketization of Universities as an antidemocratic act which has a negative effect on freedom and sociality. Giroux (1996) believes that the policy pushes the universities toward a competitive environment managed by the principals of the social Darwinism: "the fittest survive and the weakest removed". In such environment, higher educational institutions work with uncertainty about future funds and resources.

As Mirzamohammadi and Mohammadi (2017) point out New Public Management (NPM) is a fundamental step toward the marketization of higher education. NPM seeks to change the form of management according to market and consider work relations as principal-agent hierarchy, so that services are evaluated based on cost and quality (Olssen $\&$ Peters, 2005). In this situation, universities work in a competitive environment and survive based on their success in absorbing wealthy consumers, advertisement, cost-cutting programs and so on.

Mirzamohammadi and Mohammadi (2017) also add that the NPM tries to decrease the reliance of the higher education institution on the government financial support as much as possible and increase its performance and efficiency. Therefore, government becomes free of financial support and at the same time it has control on higher education via bio politics. Generally speaking, NPM has an anthropological and philosophical point of view and its final destination is 'capitalization of the existence itself' (Davies \& Bansel, 2007), and providing human capital for realization of capitalism not only as a mode of economic system, but as a way of life, a worldview, and as a mode of being. In such environment, teachers lose their autonomy and have to adapt to market oriented rules, and their success is dependent on the transferring of teaching and researching activities to salable goods (Aronowitz \& Giroux, 2000).

\section{The IMPLiCATIONS OF MARKETIZATION IN Higher EDUCATION}

As Lynch (2006) asserts, one of the main implications of the marketization of education is shifting cultures which encompasses not only teachers and educational staffs but also students. When the university is transformed from being a teaching and learning environment to a business organization and productivity becomes the criterion for its success, the whole scenario changes and being operational becomes the proof for allegiance instead of being academia (Doring, 2002, citing McNair, 1997). Gratifying performances item by item creates a situation in which personal career interests determines academic life. In this situation, everything and everyone is audited and measured and performance is the indicator (Leathwood, 2005). So no one is confident about the feeling of self-authenticity and being valued and the culture of compliance is created and performance is consistently under the control (Cooper, 2000, cited in Rutherford, 2005).

Another implication is related to the broader societal normative goals, which are not always in agreement with the objectives for which students are trained. Taylor and Judson (2011) assert that it is not easy to consider a long-term value creation vis-à-vis greater learning outcomes in marketized situation. Marketization creates an environment which concentrates on performance goals (value delivery) rather than learning goals (value co-creation). Actually, the value system changes dramatically in marketized conditions and poor long term outcomes that are created are harmful for individuals and the whole society.

Marketization of education has some pragmatic implications as well. As Lynch (2006) asserts, when higher educational institutions evaluate themselves based on transaction- specific value instead of end-state value, they prefer value delivery system to value co-creation and the fundamental responsibility of the higher education institution which is pushing students toward intellectual achievements (like critical thinking and evaluation) is neglected.

Lynch (2006) also points to the threat to critical voices as another important implication of marketization. Making the universities market-oriented threatens the issues of critique and creativity in researches which are really important. When universities are limited to contract researches, they do not have the required time for critical and creative issues, as there is a short of time for publishing the articles. This trend also has a negative effect on the position of humanities and critical social sciences as they do not serve the for-profit sector directly. Lynch (2006) also claims that transforming higher education institutions to corporations and creating a market-oriented view may transfer the resources to outside where there is no public control. As an example, public universities of USA can't afford good researchers and they are employed by private sectors which offer higher salaries (Smallwood, 2001).

\section{CURRICUlum DEVELOPMENT}

Education is crucial in developing a nations' personality. As stated in the theme of National Education Day on May $2^{\text {nd }} 2010$, education aims to build a good character and to build a civilized nation. Education plays an important role in improving knowledge, skill and morality. Therefore, a good education system is needed not only to build a better nation 
but develop a better country. Education consists of different factors that are complementary. Curriculum and syllabus are two elements that assist an education to work effectively and result a desirable output.

Curriculum development encompasses the processes needed to do the needs analysis for a group of learners, to set goals and develop objectives in order to cover those needs, to design a good syllabus, to determine teaching methods and materials, and to evaluate the program (Richards, 2001). Syllabus and curriculum are closely related in learning and teaching process. As a matter of fact, curriculum is a broader concept that encompasses all the activities of the students including whatever they learn, how they learn, how teacher help them learn, what are the supporting materials needed, and what methods are used in learning and teaching process. Similar to Richards (1990), Brown (1995) asserts that, needs analysis, goals setting, testing, materials, teaching and evaluation are the primary elements of curriculum design. As mentioned before, curriculum is a fundamental element of any educational system and it is not separated from social or political contexts, so the question which arises here is that "what happens when educational context becomes marketized?"

\section{CURRICULUM IN MARKETIZED EdUCATION}

In the present era of internationalization and globalization, neoliberalism and marketization agendas have become fundamental elements of higher educational policies. One of the major aspects of these agendas is their effect on the curriculum. Marketization of higher education has changed the kind of knowledge and skills that are emphasized in curricula according to market and economic needs and based on the goal of developing human capital required to support economic growth. Accordingly, as Savage (2017) asserts, utility of the curriculum in terms of preparing students with skills and competencies required for participation in the global knowledge economy has become the criterion based on which curriculum is being reshaped and evaluated. Accordingly, many terms have been used for this trend, such as 'utilitarian curriculum' (Goodson, 1997), 'technical-instrumentalism' (Young, 2008), 'new vocationalism' (Wheelahan, 2010), and 'economization of curriculum' (Savage, 2017).

As Savage (2017) points out, globalization and technological developments force curriculum developers to revise the discipline-based curriculum, as it is focused on preparing students for the jobs that may not exist any longer in the near future. Zhao (2009) asserts that "we live at the heart of a global and technological revolution, which at least rivals the industrial revolution" (p. 145). He adds that this revolution is continuously changing societies and making new skills and knowledge needs. Zhao (2009) also studies US and developed countries and their agendas regarding curriculum development and points to the necessity of including new fundamental skills and forms of knowledge, including critical thinking, problem solving, information technology skills, and knowledge in important fields like English and economics (pp. 145-148).

The market-orientation of the higher educational institutions has led them to concentrate on developing curricula which are in line with international standards and compete well in the global market. In this situation the importance of knowledge gives its place to the logics of market and economic competitiveness and performance is overvalued than knowledge (Nixon, 2013). In other words, there is a shift from concentration on the importance of knowing (knowledge) to the importance of doing (performance) and marketable skills have become the priority of the curriculum developers.

Some countries like Australia have concentrated on developing curricula that facilitates the goal of equipping students with skills that help them live and work successfully in the new era. As an example, the new curriculum of Australia encompasses seven general competencies: literacy, numeracy, information and communication technology (ICT) capability, critical and creative thinking, personal and social capability, ethical understanding, and intercultural understanding (Savage, 2017). These general competencies are meant to be the integral part of each curriculum of every field to prepare students to engage in the changing economic contexts. Consequently, as Savage (2017) claims, the new agenda expresses the desire to create a new citizen. The citizen who is literate, numerate, flexible, creative, is competent in IT, and the one who is ready to compete in the global knowledge economy. In this sense, education is moving towards the prerequisites of the global capitalism and economic needs, rather than the issue that is valuable by itself and the democratic role of education in producing active and informed citizens is threatened.

'If the schools of a democratic society do not exist for and work for the support and extension of democracy, then they are either socially useless or socially dangerous.' (Mursell, cited in Beane \& Apple, 2007). This claim reminds us not to forget democracy. In this regard, curricula have two roles: educating democracy which means serving it, and being democratic. As Reid (2005) suggests, a democratic curriculum develops all the capabilities evenly and is not confined to particular roles and needs of the society but clearly curriculum developers of the marketized education doesn't follow it and take a cost-benefit perspective.

As Pinar (2004) asserts "curriculum ceases to be a thing, and it is more than a process. It becomes a verb, an action, a social practice, a private meaning, and a public hope. Curriculum is not just the site of our labor, it becomes the product of our labor, changing as we are changed by it...It is an ongoing, if complicated, conversation "(p. 188). Accordingly, teaching is a political act (Keirl, 2007), curriculum is political as well and advances particular interests and values (Apple and Buras, 2006; Burke and Jackson, 2007). But educational institutions around the world should work towards 'maintaining a sense of the international public good, and helping to develop a strong world- wide academic culture' (Altbach, 2016). Material developers and curriculum designers should consider the effects of 
marketization on education which is the prevailing trend nowadays, and do the work with a comprehensive understanding of the situation to produce the best curriculum that leads to the desired goals.

\section{CONCLUSION}

The civil mission of higher education used to be the instruction of students and producing knowledgeable thinkers, and creating non-utilitarian knowledge (Askehave, 2007; Kwong, 2000). Until the last decade, higher education was kept isolated from market orientations, but globalization changed every field including education. The growth of the global economy and the pressure of national and international competitions persuaded higher educational institutions to resort different financial resources (Askehave, 2007; Osman, 2008; Mok, 1999, 2000), such as absorbing fee-paying students and developing marketable "products" (Askehave, 2007). Consequently, the process of marketization of higher education started and universities took a market-oriented point of view and changed to "corporate universities" (Jarvis, 2001) and became business-like entities (Connell \& Galasinski, 1998).

Overall, the marketization of higher education has become a new trend in today's world. It has become a business from which many are making profit. There has been a widespread competition among higher educational institutions for better students, and making money rather than following learning goals has become the main object of many them. They are making attempts to be the most successful and this new trend has dramatically affected many educational fields including teacher's identity and curriculum design.

Regarding teacher's identity, it should be pointed out that it is not defined in a vacuum, but in its social context. It is defined in discourses and communities where teachers live. The process of marketization has had a negative impact on teacher's identity. When universities act like corporates, teachers lose their usual social position as a symbol of wisdom; they view education as a commodity, and they should try to absorb wealthy customers (Giroux, 2006). What is clear is that there is a different "preferred teacher" in the marketized educational contexts. As Smyth (2011) also asserts, the preferred teacher of this trend is the one who is dutiful, obedient, market-sensitive, and uncritical of the conditions around, especially those that are related to the marketization agendas that are implementing in educational contexts. Marketization has obstructed teachers' creativity and has led to a sense of uncertainty. Teachers in marketized education have to respond to the needs of higher educational institutions, and as a result they lose their freedom and authority. They may also feel devalued and have to respond to the outside world. Therefore, they have lost control over their work.

Curriculum has also been affected by the marketization of higher education. It has been designed in such a way to provide students with skills which are necessary for participation into global knowledge economy. In fact, the economization of curriculum is inevitable in this situation. The curriculum in the marketized education does not provide students with critical thinking and problem solving information. The curriculum creates human beings which would be able to meet economic needs, and the role of active and knowledgeable citizens is ignored.

The fact of the matter is that marketazation of higher education is a phenomenon taking place in many countries including Iran. The number of universities in this country with a population of 70 million people is even more than USA. Universities such as Islamic Azad University, Payame Nour University, and Elmi Karbordi University have established a new trend in education, leading it to being marketized. A serious threat which has emerged is that students expect to be passed by their professors just because they pay money, and professors are under pressures to do so. These universities have to be able to deal with their financial affairs themselves without the government' assistance. As a result, the number of those who fail courses is dramatically low because unless the number is maintained, these institutions will face fiasco. In this way, professors view themselves as money makers for their institutions. They do not anymore consider themselves as those helping students to learn deeply.

A good example of marketization in Iran is the establishment of Elmi Karbordi University, which has focused on performance rather learning outcomes. Students might learn to function in society, but they lack enough critical skills and learning insight. Professors regard themselves as those who should equip their students with some performance skills rather than appropriate learning outcomes.

The marketization of education has also penetrated into state universities. The establishment of Pardisan Universities is a good example in this regard. As mentioned already, this phenomenon can have negative and harmful effects on the society in general. State University officials have tried to compensate for their financial deficiencies by Pardisan Universities. As an example, many medical students enter these institutions and they are expected to treat patients in the future. Although these students rank low in the university entrance examinations, just because they are wealthy, they can register in these universities. Now the question is how they can perform their important duties regarding human bodies. Worst of all, there is a competition among these universities to attract a greater number of wealthy students. The reason is that their survival is contingent upon more and more students. The widespread and unsystematic marketization in Iran has caused a disproportionate distribution of students, which has not benefitted either of these universities.

The fact that education is a social institution that has not managed to reach its historic democratic and equalitarian missions does not mean that we should give up trying. A significant rethink of marketization policies is needed. As more individuals learn about the effects of marketization on higher education, new opportunities open up to think about this trend in a different way and take required steps to reshape the direction. Educators should also understand the effects of marketization policies on education and their roles in reshaping the educational conditions and how they 
influence everyday life. Because without such understanding, they cannot participate well in changing the direction of the reform.

Of course, it is not logical to think of marketization as a sole negative trend. The truth is that an uncritical view of marketization of higher education that considers it as an 'all evil' force is just as unhelpful as an uncritical celebration of its benefits. Instead, we (including researchers, educators, principals, students, policymakers, and so on) should have a continuous and critical engagement in different aspects of education to make it better for everyone in the society.

\section{REFERENCES}

[1] Angus, L. (2013). Teacher identity and the neoliberal condition: Asserting a participative-professional, socially democratic teacher imaginary in technical-managerial time. Journal of Educational and Social Research. 3(7): 170-177. MCSER Publishing, Rome-Italy.

[2] Aslan, G. (2013). Neo-liberal transformation in Turkish higher education system: A new story of a turning point: Draft proposition on the higher education law. (pp: 255-283). Gaziosmanpasa University, Tokat, Turkey. file:///C:/Users/Solmaz/Desktop/neoliberalism\%20in\%20Turkey (accessed 8/7/2019).

[3] Bartlett, L., Fredrick, M., Gulbrandsen, TH. \& Murillo, E. (2002). The marketization of education: Public schools for private ends. Anthropology \& Education Quarterly. Vol. 33 (1): pp. 5-29https://www.researchgate.net/publication/237511064 (accessed 8/7/2019).

[4] Beijaard, D., Meijer, P. C., \& Verloop, N. (2004). Reconsidering research on teachers' professional identity. Teaching and Teacher Education 20(2004): 107-128. Leidon University, The Netherland.

[5] Borazjani, Z., \& Bagheri, M. S., (2016). Strengths and weaknesses of educational equity in English language teaching at Iranian and Finnish primary and secondary schools. Journal of Studies in Learning and Teaching English, 5(1): 55-75. Islamic Azad University Shiraz, Iran.

[6] Brown, R. (2014). The marketization of higher education: Issues and ironies. HE Policy. Vol. 1(1): 4-9. Liverpool Hope University, UK.

[7] Brown, Roger (2015). The marketization of higher education: Issues and ironies. New Vistas, Vol. 1(1): 4-9.

[8] Clarke, M. (2008). Language teacher identities co-constructing discourse and community. Library of Congress Cataloging in Publication Data.

[9] Danielewicz, J. (1995). Teaching selves: Identity, pedagogy, and teacher education. State University of New York Press. USA.

[10] Dugas, D., Summers, K. H., Harris, L. N., \& Stich, A. E. (2018). Shrinking budgets, growing demands: Neoliberalism and academic identity tension at regional public Universities. AERA Open, 4(1): 1-14. Northern Illinois University. http://journals.sagepub.com/home/ero (aceessed 11/8/2019).

[11] Felgueira, T., \& Rodrigues, R. G. (2014). Market orientation of teachers and researchers in higher education institutions: a new approach. Social and Behavioral Sciences 174 (2015): 3017 - 3024.

[12] Giroux, H. (2002). Neoliberalism, Corporate Culture and the Promise of Higher Education: the university as a democratic public sphere. Harvard Educational Review, 72(4), pp. 1-31.

[13] Gul, H., Gul, S. S., Kaya, E., \& Alican, A. (2010). Main trends in the world of higher education, internationalization and institutional autonomy. Procedia Social and Behavioral Sciences 9 (2010): 1878-1884.

[14] Gyamera, G. O., Burke, P. J. (2017). Neoliberalism and curriculum in higher education: A post-colonial analyses. Teaching in Higher Education (pp: 1-18). https://doi.org/10.1080/13562517.2017.1414782 (accessed12/8/2019).

[15] Hall, D., \& McGinity, R. (2015). Conceptualizing teacher professional identity in neoliberal times: Resistance, compliance and reform. Education Policy Analysis Archives, 23(88): 1-21. http://dx.doi.org/10.14507/epaa.v23.2092 (accessed 12/8/2019).

[16] Izadinia, M. (2014). Teacher educators' identity: a review of literature. European Journal of Teacher Education, (pp: 1-16). Edith Cowan University, Perth, Australia. http://dx.doi.org/10.1080/02619768.2014.947025 (accessed 8/7/2019).

[17] Jessee, P. El. (2010). Knowledge, the marketization of education, and high-stakes accountability: Curriculum differentiation in Chicago public high schools. Master's Theses Paper 546, (pp: 1-81). http://ecommons.luc.edu/luc_theses/546 (accessed 12/7/2019).

[18] Judson, K. M., Taylor, S. A. (2014). Moving from marketization to marketing of higher education: The co-creation of value in higher education. Higher Education Studies, 4(1):51-67. Illinois State University, Normal, Illinois, USA.

[19] Keirl, S. (2015). Against Neoliberalism; For Sustainable-Democratic curriculum; Through Design and Technology Education', in Stables, K. \& Keirl, S., (Eds.), (2015), Environment, Ethics and Cultures: Design and Technology Education's Contribution to Sustainable Global Futures, (pp. 153-174), Sense, and Rotterdam.

[20] Lankveld, T. V., Schoonenboom, J., Volman, M., Croiset, G., \& Beishuizen, J. (2016). Developing a teacher identity in the university context: a systematic review of the literature. Higher Education Research \& Development, 36(2): $325-342$. https://doi.org/10.1080/07294360.2016.1208154 (accessed5/7/2019).

[21] Lundahl, L., Arreman, I. E., Holm, A. S., \& Lundstrom, U. (2013). Educational marketization the Swedish way. Education Inquiry, 4(3): 497-517.

[22] Lynch, K. (2006). Neo-liberalism and marketization: The implications for higher education. European Educational Research Journal, 5(1): 1-17. University College Dublin, Republic of Ireland.

[23] Maguire, M. (2002). Globalization, education policy and the teacher. International Studies in Sociology of Education 12(3): 261-276. King's College, London, United Kingdom.

[24] McKnight, L. (2016). Meet the phallic teacher: Designing curriculum and identity in a neoliberal imaginary. Australia Educational Research, 43:473-486. https://www.researchgate.net/publication/305645595 (accessed 2/7/2019).

[25] Mets, K., Timostsuk, I., \& Ugaste, A. (2015). The impact of neoliberal educational reforms on teachers learning experiences. The European Proceedings of Social \& Behavioral Sciences. eISSN: 2357-1330. http://dx.doi.org/10.15405/epsbs.2015.08.16 (accessed 8/7/2019). 
[26] Mirzamohammadi, M. H., \& Mohammadi, H. (2017). Neoliberalism and higher education in Iran: A critical perspective. Problems of Education in the 21st Century, 75(5): 467-482.

[27] Mockler, N. (2013). Teacher professional learning in a neoliberal age: Audit, professionalism and identity. Australian Journal of Teacher Education, 38(10): 35-47. http://dx.doi.org/10.14221/ajte.2013v38n10.8 (accessed 10/7/2019).

[28] Richards, J. C. (2001). Curriculum Development in Language Teaching. Cambridge: Cambridge University Press. http://dx.doi.org/10.1017/CBO9780511667220 (accessed 10/8/2019).

[29] Richardson, V., \& Placier, p. (2001). Teacher change. In V. Richardson (Ed.), Handbook of research on teaching (pp. 905-947). Washington, DC: American Educational Research Association.

[30] Rodriguez, A., \& Magill, K. R., (2016). Diversity, neoliberalism and teacher education. International Journal of Progressive Education, 12(3): 7-23.

[31] Sardoc, M., \& Giroux, H. (2018). The language of neoliberal education: An interview with Henry Giroux. (pp. 1-37). https://www.researchgate.net/publication/329774785 (accessed 13/7/2019).

[32] Savage, G. C. (2017). Neoliberalism, education and curriculum. University of Western Australia. (pp. 143-165). https://www.researchgate.net/publication/320069681 (accessed 12/8/2019).

[33] Shahghasemi, E. (2017). Commodification of education in Iran. $7^{\text {th }}$ International Research Conference on Education, Language and Literature. IRCEELT 2017. Tbilisi, Georgia.

[34] Taylor, S.A. \& Judson, K. M. (2014). Moving from marketization to marketing of higher Education: The co-creation of value in higher education. Higher Education Studies, 4(1): 57-67. Illinois State University, Normal, Illinois, USA.

[35] Zhang, T. (2017). The marketization of higher education discourse: A genre analysis of university website homepages in China. Higher Education Studies, 7(3): 64-79. Guangdong University of Foreign Studies, Guangzhou, China.

[36] Zhao, Y. (2009). Catching up or leading the way: American education in the age of globalization. Alexandria, VA: ASCD.

Yaghoob Javadi, $\mathrm{PhD}$ is an assistant professor of Applied Linguistics at Department of Language Teaching and Translation Studies at Islamic Azad University, Varamin-Pishva branch, Iran where he teaches post-graduate courses including Second Language Acquisition Studies, Curriculum Planning, Computer Enhanced Language Learning, and Language, Culture and Identity. His current research interests include cultural and cognitive aspects of second language acquisition, identity, CALL, curriculum planning and teacher education.

Solmaz Azizzadeh Asl is a PhD candidate in TEFL at Department of Language Teaching and Translation Studies at Islamic Azad University, Varamin-Pishva branch, Iran. She has been teaching English at language institutions of Tehran and Sari for more than five years. She also translates English books and texts for different organizations. Her current research interests include extensive reading and identity. 